\title{
The effect of substrate temperature on the physical properties of spray pyrolysed CdS thin films
}

\author{
T.A. Abbas A.O. Jafir \\ Department of physics / College of Science \\ University of Salahaddin / Kurdistan region, Iraq.
}

Received

22 / 11 / 2010
Accepted

12 / 04 / 2011

\section{الخالصة}

في هذا البمث، قم تحضير أغثيه رقيقه لشبه الموصل CdS على قواعد زجلجية

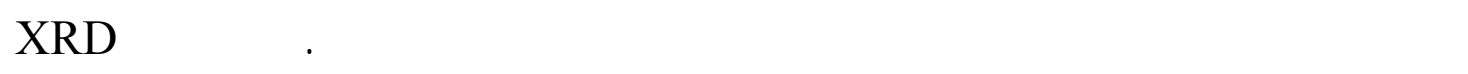

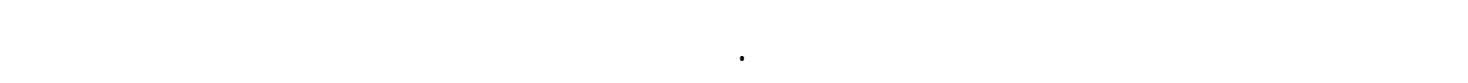
الأطول الموجية (300-900 nm) تمت درلسة الخواص البصرية للأغثية. مق إيجاد قيم

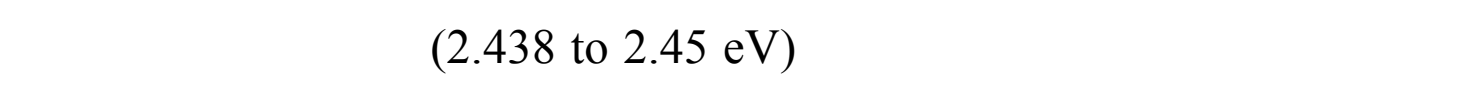
القاعدة الزجلجية (20 $375^{\circ}$ (325 to

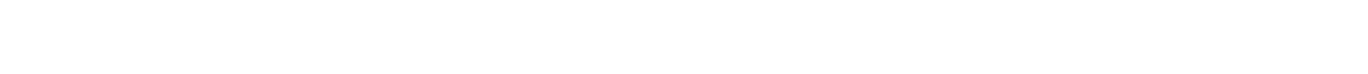

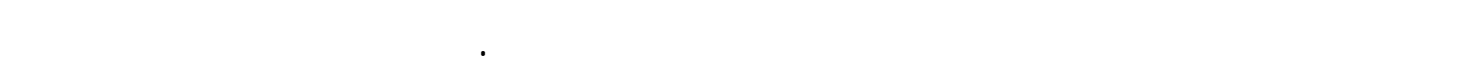

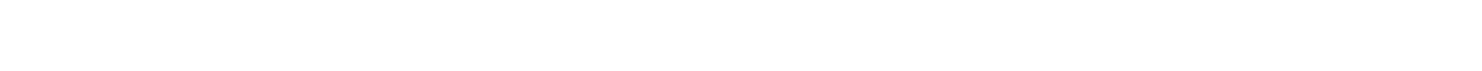
التنشيط للأغثية.

\begin{abstract}
Cadmium sulphide (CdS) thin films with different substrate temperatures were prepared on glass substrates by spray pyrolysis technique. XRD patterns indicated the presence of single- phase hexagonal CdS. UV-VIS spectra of the films in the spectral region from $300 \mathrm{~nm}$ to $900 \mathrm{~nm}$ were studied using the optical transmittance measurements which were taken. The direct band gap energy of the films was found to be increasing from 2.44 to $2.45 \mathrm{eV}$ with increased substrate temperature from 325 to $375{ }^{\circ} \mathrm{C}$. The electrical conductivity of the films was found to be increase as the substrate temperature. The annealing effect in air increases the dark conductivity while the activation energy decreased.
\end{abstract}

Key words: CdS thin films; spray pyrolysis; structure; optical and electrical properties. 


\section{1- Introduction}

$\mathrm{CdS}$ is a yellow compound and can be found in nature as the mineral Greenockite. It is formed by introducing hydrogen sulfide $\left(\mathrm{H}_{2} \mathrm{~S}\right)$ into alkaline cadmium salt solution ${ }^{[1]}$. And it is one of the most studied compounds with a direct band gap of about $2.42 \mathrm{eV}$ at $300 \mathrm{~K}$, the magnitude of its band gap means that it appears colored ${ }^{[2]}$. Thin films of $\mathrm{CdS}$ are of considerable interest for their efficient of solar cell and other optoelectronic devices. The deposition of CdS films has been explored by different techniques: thermal evaporation ${ }^{[3,4]}$, sputtering ${ }^{[4,5]}$, close space sublimation ${ }^{[6,7]}$, laser ablation ${ }^{[8]}$, chemical bath deposition ${ }^{[9,10]}$, 'electro deposition $^{[4,11]}$ and spray pyrolysis technique ${ }^{[12,13]}$. Spray pyrolysis is one of the chemical techniques applied to form a variety of thin films ${ }^{[14]}$.

The aim of this work is to prepare CdS thin films by spray pyrolysis technique and to investigate their structure, optical end electrical properties for different substrate temperatures.

\section{2- Experimental details}

In this study, cadmium sulphide thin films were deposited on glass substrates using spray pyrolysis technique. The process is quite simple in that the constituents are contained in aqueous solution of a metallic salt and an organic compound of sulfur. The cadmium and sulfur in solution are atomized by the pressure of a gas which drives them through the nozzle of a spray. The spray mixture is incident on a heated substrate. Cadmium chloride and thiourea in solution form a complex which is a suitable starting material to produce satisfactory $\mathrm{CdS}$ films ${ }^{[15]}$. The experiment set-up for the process is diagramed in Fig (1). Thin films of $\mathrm{CdS}$ were deposited on glass substrate cleaned to achieve succeful deposition. The solution was atomized by a special glass nozzle sprayer with a diameter of about $(0.34 \mathrm{~mm})$, with the help of $\left(\mathrm{N}_{2}\right)$ as a carrier gas of pressure $(2.2$ bar), and spray rate about $(40 \mathrm{ml} / \mathrm{min})$, directed at the heated glass substrate which is inside the furnace which controlled by thermocouple. The distance between the spray nozzle and the surface of the substrate is about $30 \mathrm{~cm}$, the angle and the direction of the spray remain critical factors in obtaining homogenous layer of $\left(45^{\circ}\right)$. The solution reaches the substrate at a temperature range $\left(325-375^{\circ} \mathrm{C}\right)$ in the form of small droplets where they are decomposed. The elements react endothermic ally and they are deposited as a thin film, where as the other unstable species are evaporated. The spraying period was $(6 \mathrm{~s})$ which was followed by ( $53 \mathrm{~s}$ ) wait to avoid excessive cooling of the substrate. When the deposition completed, the samples were left on the heater for about 30 min. in order to obtain chemical interactions and the re crystallization will be complete. 
1-nitrogen tank 2-gauge 3-gas flow meter 4-spray timer 5- Temp.controller 6-thermocouple 7-heater 8-sample 9-nozzle 10-solution 11-exhaust fan 12-wood chamber
$(2)$

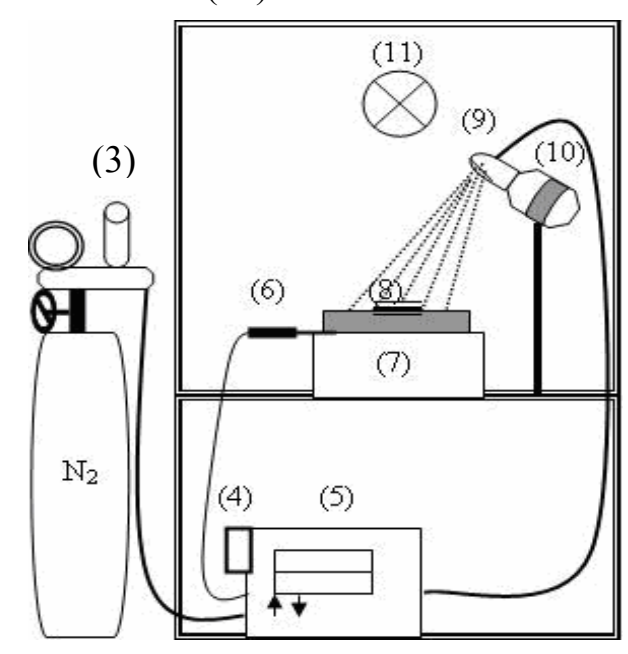

Fig. (1): Schematic diagram of the spraying apparatus.

\section{3- Results and discussions}

\section{3-1 structure}

CdS thin films deposited by chemical spray pyrolysis technique onto the glass slides were examined by X-ray diffraction technique to find the structural characterization of the films. Fig. (2) shows the typical XRD pattern of the CdS samples for two different substrate temperatures.
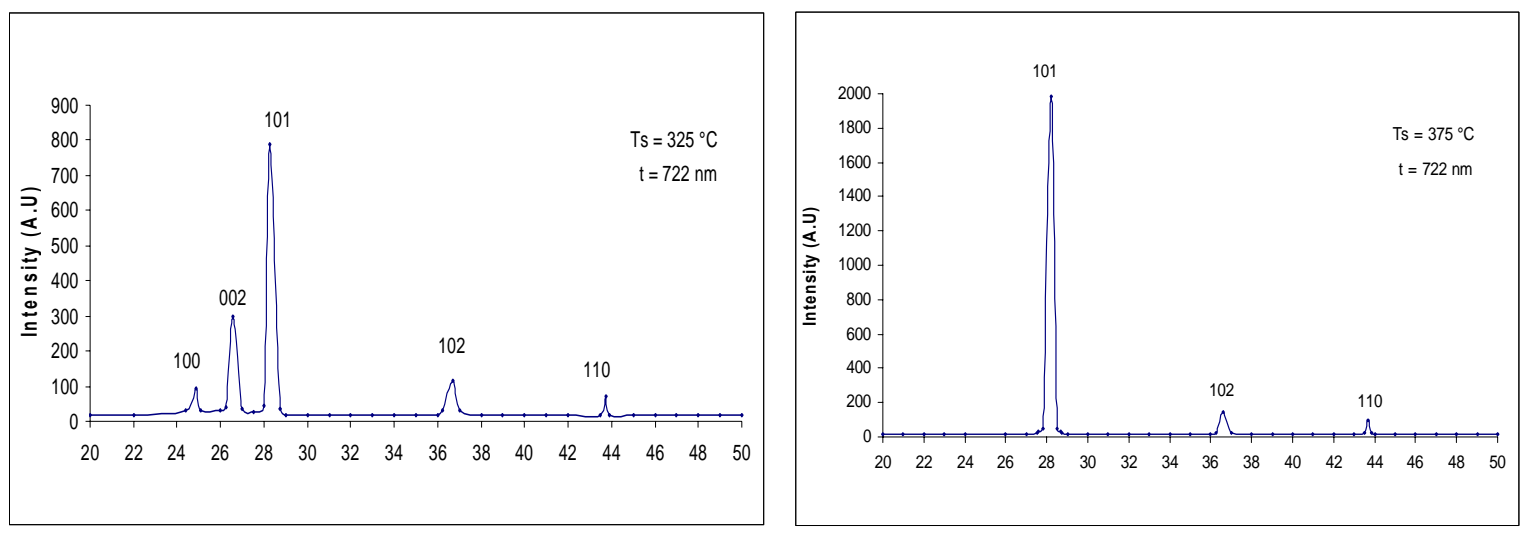

Fig:(2): XRD pattern of CdS thin films for two different substrate temperatures.

XRD analysis showed that the films have highly crystallites with hexagonal structure with a preferred orientation (101) planes. The degree of preferred orientation increased with substrate temperatures. The effect of the substrate temperature on the grain size was also investigated by using the Scherer formula ${ }^{[16]}$.

$$
D=\frac{0.9 * \lambda}{B * \cos (\theta)}
$$

where $\lambda$ is the wavelength of the X-ray used $\left(1.54060 \mathrm{~A}^{\circ}\right), B$ is the fullwidth at half-maximum of the peak which has maximum intensity and $\theta$ is the Braggs angle. 
The grain size values were found to be increases with increasing the substrate temperature, that behaviors is in agreement with that reported by Ashour $^{[12]}$ and Tepantlan ${ }^{[13]}$ respectively, thus increasing the substrate temperature decreases the density of the nucleation centers and under these circumstances, a smaller number of centers start to grow, resulting in large grains. The obtained lattice parameter values for two different substrate temperatures are given in table (1).

Table (1): Obtained lattice parameter and grain size values for two different substrate temperatures $(\mathrm{t}=722 \mathrm{~nm})$.

\begin{tabular}{|c|c|c|c|c|c|c|c|c|c|c|c|c|c|c|}
\hline \multicolumn{5}{|c|}{ Standard data ASTM } & \multicolumn{5}{|c|}{ Observed data at $\mathrm{Ts}=325^{\circ} \mathrm{C}$} & \multicolumn{5}{|c|}{ Observed data at Ts $=375^{\circ} \mathrm{C}$} \\
\hline $\begin{array}{c}\mathrm{d} \\
\left(\mathrm{A}^{\circ}\right)\end{array}$ & plane & $\begin{array}{c}\mathrm{a} \\
\left(\mathrm{A}^{\circ}\right)\end{array}$ & $\begin{array}{r}\mathrm{c} \\
\left(\mathrm{A}^{\circ}\right)\end{array}$ & $\mathrm{c} / \mathrm{a}$ & $\begin{array}{r}d \\
\left(A^{\circ}\right)\end{array}$ & $\begin{array}{r}\mathrm{a} \\
\left(\mathrm{A}^{\circ}\right)\end{array}$ & $\begin{array}{r}\mathrm{c} \\
\left(\mathrm{A}^{\circ}\right)\end{array}$ & $\mathrm{c} / \mathrm{a}$ & $\begin{array}{l}\text { Grain } \\
\operatorname{size}\left(\mathrm{A}^{\circ}\right)\end{array}$ & $\begin{array}{r}d \\
\left(A^{\circ}\right)\end{array}$ & $\begin{array}{c}\mathrm{a} \\
\left(\mathrm{A}^{\circ}\right)\end{array}$ & $\begin{array}{r}\mathrm{c} \\
\left(\mathrm{A}^{\circ}\right)\end{array}$ & $\mathrm{c} / \mathrm{a}$ & $\begin{array}{r}\text { Grain } \\
\operatorname{size}\left(\mathrm{A}^{\circ}\right)\end{array}$ \\
\hline 3.583 & 100 & \multirow{6}{*}{4.136} & \multirow{6}{*}{6.713} & \multirow{6}{*}{1.623} & 3. 579 & \multirow{6}{*}{4.13} & \multirow{6}{*}{6.706} & \multirow{6}{*}{1.623} & \multirow{6}{*}{281.349} & $\ldots \ldots$ & \multirow{6}{*}{4.131} & \multirow{6}{*}{6.73} & \multirow{6}{*}{1.629} & \multirow{6}{*}{$\begin{array}{c}404 \\
299\end{array}$} \\
\hline 3.357 & 002 & & & & 3. 353 & & & & & 3. 355 & & & & \\
\hline 3.16 & 101 & & & & 3.155 & & & & & 3.159 & & & & \\
\hline 2.45 & 102 & & & & 2.447 & & & & & 2.451 & & & & \\
\hline 2.068 & 110 & & & & 2.067 & & & & & 2.069 & & & & \\
\hline 1.898 & 103 & & & & 1.898 & & & & & ....... & & & & \\
\hline
\end{tabular}

\section{3-2 Optical properties}

The optical transmission spectra for the deposited CdS films were recorded in the wavelength (300-900 nm). Fig. (3). shows the optical transmittance curve as a function of wavelength for $\mathrm{CdS}$ films deposited at three different substrate temperatures. From this figure it is observed that the percentage of transmission increase with increasing the substrate temperature in the low absorption region, this is attributed to the improvement in perfection and stoichiometery of the films ${ }^{[12]}$. The sharp decrease in the optical transmission at shorter wavelengths resulted from the excitation of charge carriers across the optical band gap ${ }^{[17]}$.

The reflectance spectra of the films are shown in Fig.(4). From this figure, it was observed that the overall reflectance decreases with increasing the substrate temperature.

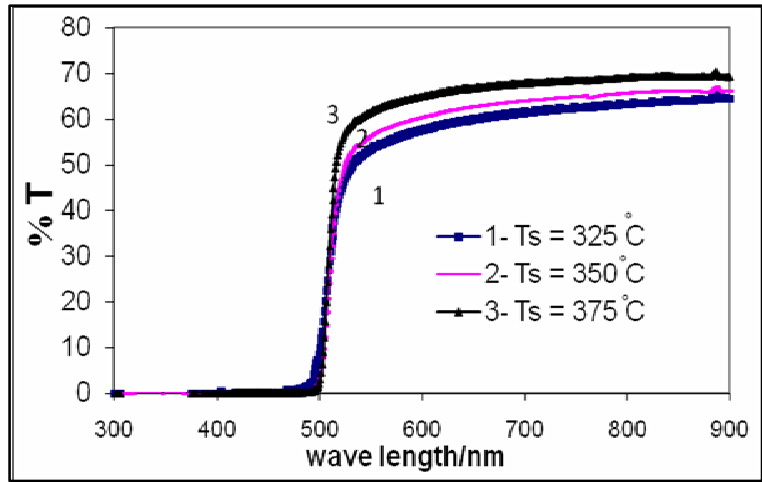

Fig. (3): Transmittance spectra versus wavelength for $\mathrm{CdS}$ films at three different substrate temperatures $(t=541 \mathrm{~nm})$.

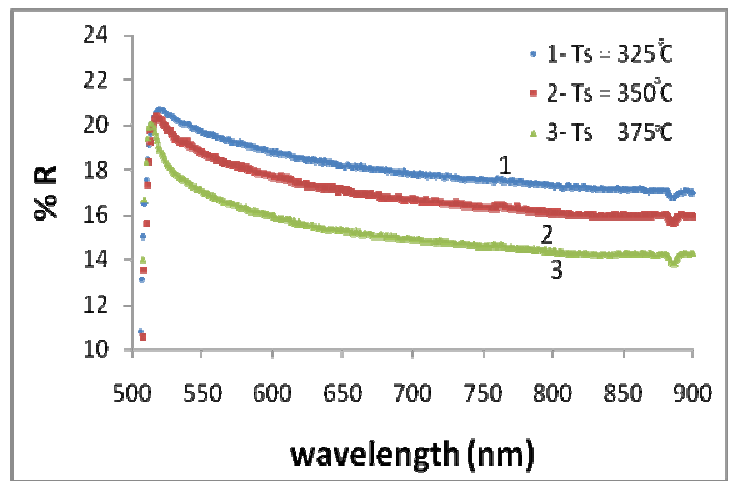

Fig. (4): Reflectance spectra for CdS

thin films at three different substrate temperatures $(t=541 \mathrm{~nm})$. 
Variation of refractive as a function of wave length is shown in Fig (5). It was observed that the increase in the substrate temperature results in the overall decrease in the refractive index. The refractive index decreases with increase the substrate temperature, when the crystalline quality is better and the crystalline size is increasing ${ }^{[13]}$.

The data point near the absorption edge can be used to determine the band gap $\left(\mathrm{E}_{\mathrm{g}}\right)$ of the samples using the relation below ${ }^{[13]}$

$$
\alpha(\mathrm{h} v)=A^{*}\left(h v-E_{g}\right)^{\frac{1}{2}}
$$

where $A^{*}$ is a constant an energy dependent. Fig. (6) Shows the variation of $[\alpha(h v)]^{2}$ against (hv) for CdS thin films deposited at three different substrate temperatures. The band gap is determined by extrapolating the straight line portion of the graph to the energy axis at $\alpha=0$. From figure (6), it's clearly observed that the band gap energy increase as the deposition substrate temperature increases. This increase of energy gap with substrate temperature is similar to the work done by Ashour ${ }^{[12]}$ and Tepantlan ${ }^{[13]}$.

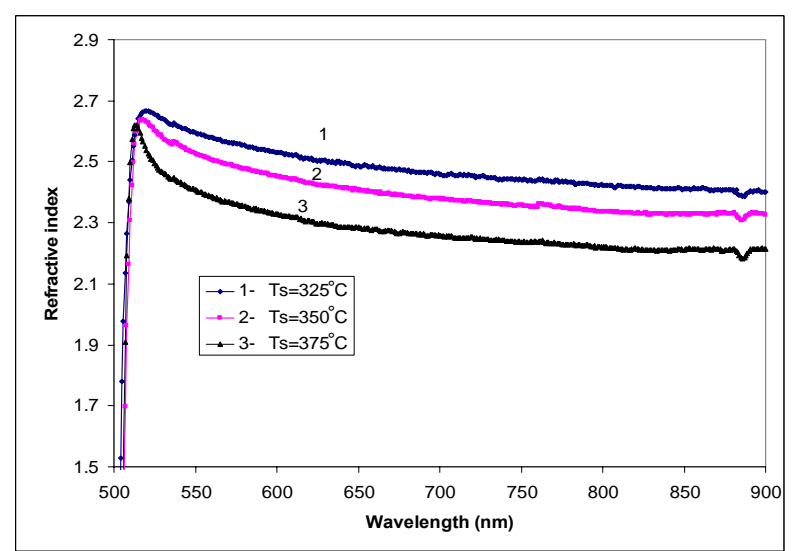

Fig. (5): variation of refractive index versus wavelength

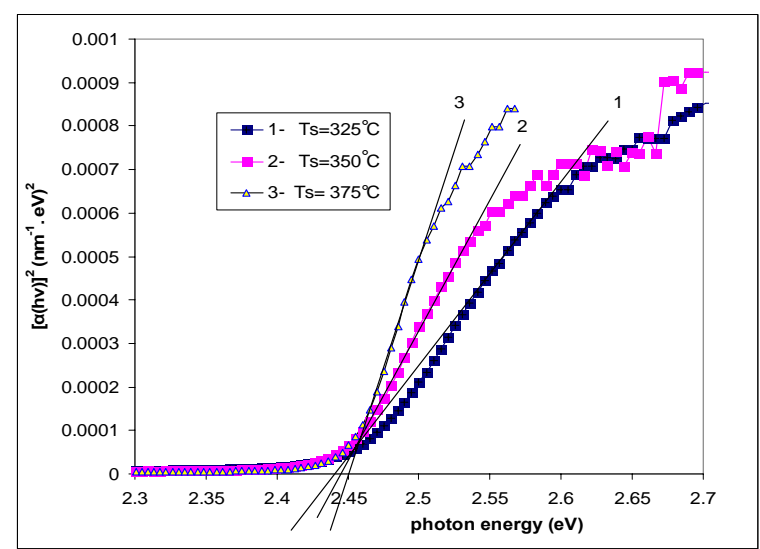

Fig. (6): Variation of $[\alpha(h v)]^{2}$ with photon energy.

Variations of extinction coefficient as a function of wavelength are shown in Fig. (7).from the figure it was observed that the extinction coefficient decreases with increasing wavelength in the vicinity of absorption edge. The decrease of $\mathrm{k}$ in this region is due to the absorbance.

Fig. (8) and (9) shows variation in real and imaginary of dielectric constant as a function of wavelength. The variations of real and imaginary part of dielectric constant have the same behaviors of refractive index and extinction coefficient respectively. 
The effect of substrate temperature on the physical properties of spray ...

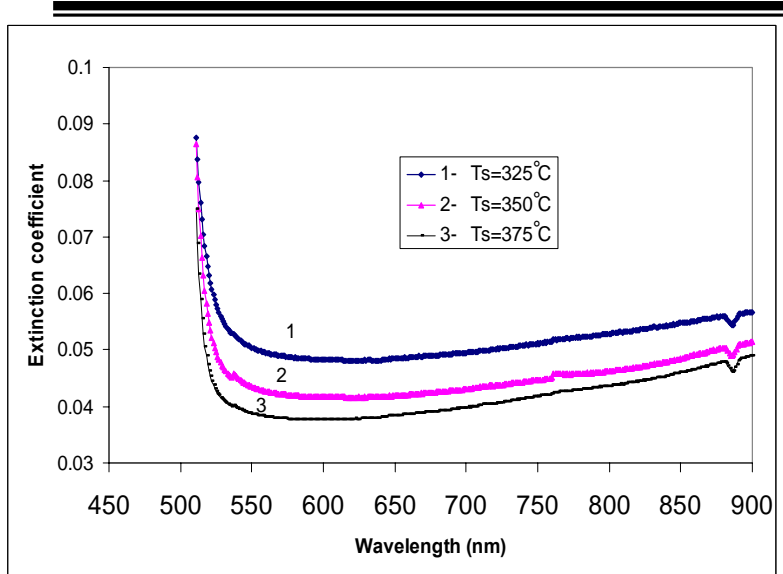

Fig (7): Variation of extinction coefficient with wavelength.

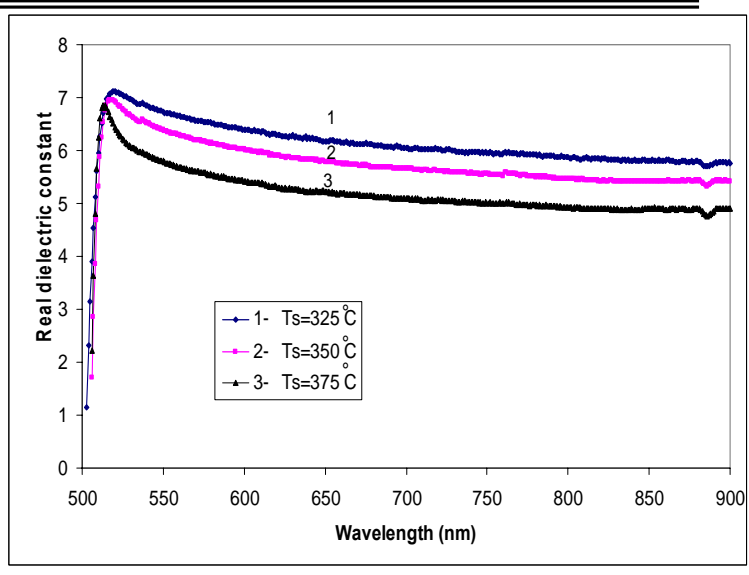

Fig (8): Variation of refractive index with wavelength

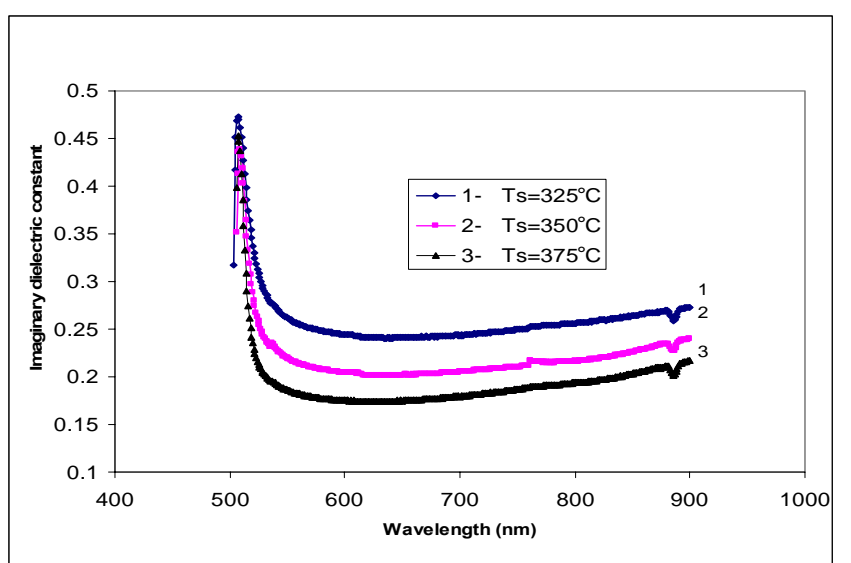

Fig (9): Variation of imaginary dielectric with wavelength.

\section{3-3 Electrical properties}

Current-voltage characteristic was carried out to investigate the electrical properties of the Al- CdS contact. In electronics, the relation between the d.c current through an electronic device and the d.c voltage across its terminals is called a current-voltage characteristic of the device. Fig. (10) Shows the relation between the current and the voltage of CdS film which is linear in both directions, indicating that the contact is Ohmic.

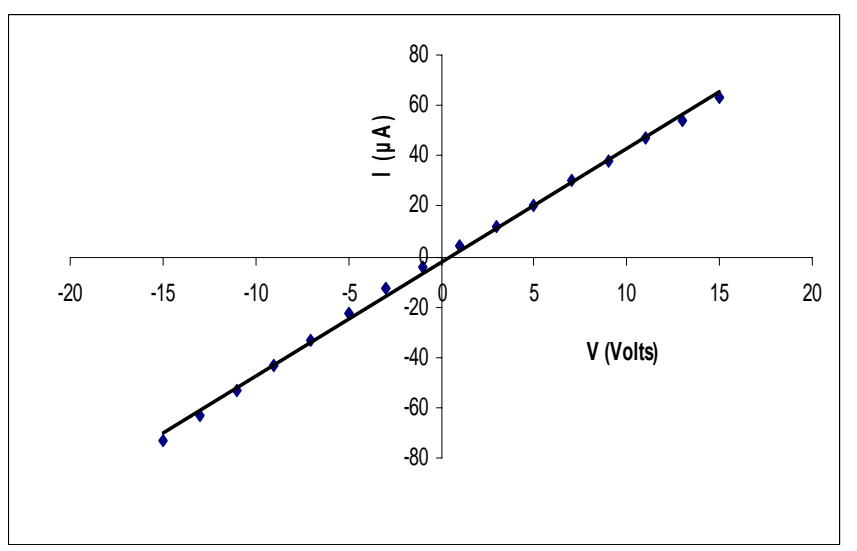

Fig. (10): I-V characteristic of the Al-CdS contact at dark and at room temperature. 
The electrical conductivity of CdS films was measured using the d.c two point probe method. Fig. (11) shows temperature dependence of the dark conductivity of $\mathrm{CdS}$ films deposited at three different substrate temperatures.

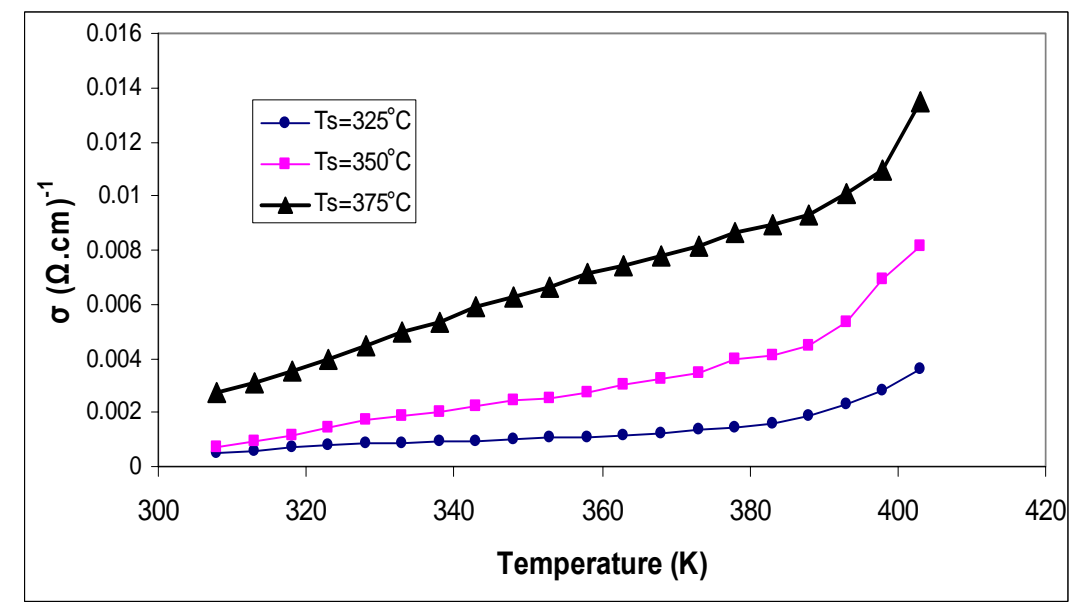

Fig. (11): Temperature dependence of dark conductivity for CdS films at three different substrate temperatures $(t=541 \mathrm{~nm})$.

From Fig. (11), it is clear that the conductivity of CdS films increased with increasing temperature indicating semi-conducting nature of the films.

A graph of $\ln (\sigma)$ against $\left(10^{3} / \mathrm{T}\right)$ should be linear with a slope equal to the activation energy (Ea) according to equation

$$
\sigma=\sigma_{\mathrm{O}} \exp \left(\frac{-E a}{\mathrm{~K}_{B} T}\right)
$$

where $\sigma \mathrm{o}$ is a constant characteristic to each semi conducting material. The variation of $\ln (\sigma)$ with reciprocal of the temperature $\left(10^{3} / \mathrm{T}\right)$ for three different substrate temperatures has been shown in Fig. (12).

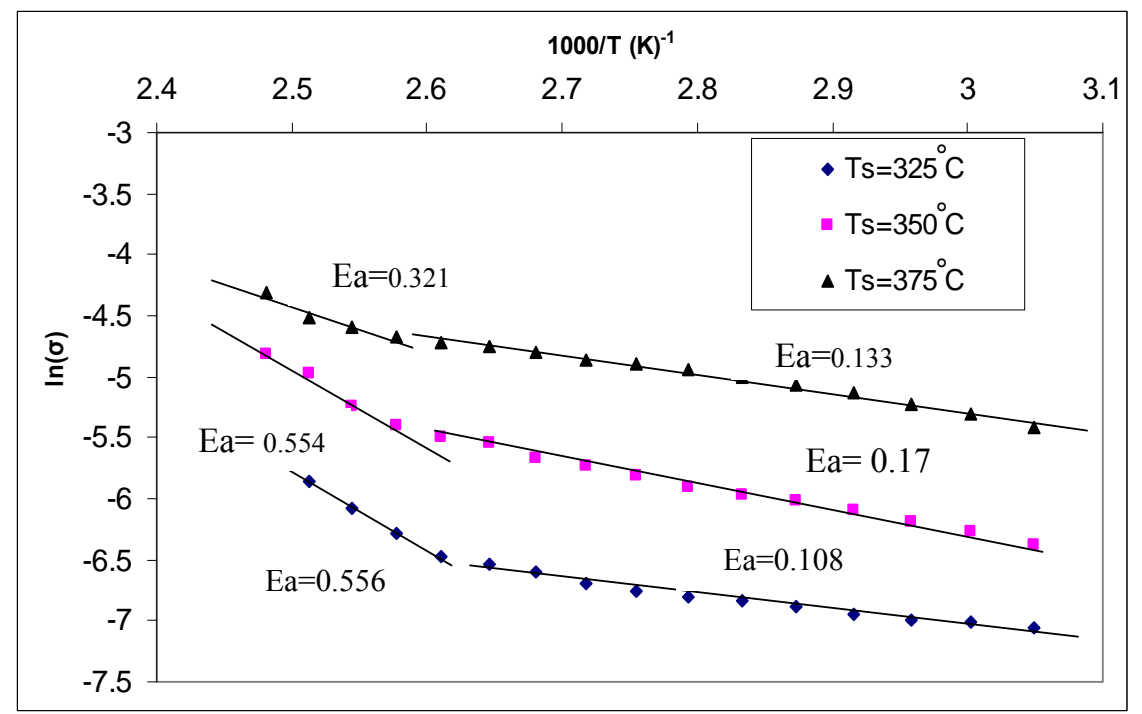

Fig. (12): Plot of $\ln (\sigma)$ versus $\left(10^{3} / T\right)$ for $C d S$ thin films deposited at three different substrate temperatures $(t=541 \mathrm{~nm})$. 
The slope of each curve in Fig.(12) gives two values of activation energy for two different temperature ranges. The values of the observed activation were found to be increased with increasing temperature. These two activation energies in the lower- and higher-temperature regions show the existence of defective complex structure. It was seen from the activation energies that the films do not posses the intrinsic conductivity strictly in this entire range of applied temperature. The results indicate the presence of two donor levels - one deep and one shallow near the bottom of the conduction band. The shallow trapping states preferably due to those interstitial cadmium or sulfur vacancies are expected to dominate the extrinsic conductivity near room temperature whereas those deep trap states influence at high temperature range ${ }^{[18]}$.

\section{Conclusion}

CdS films were prepared by spray pyrolysis technique using a solution of cadmium chloride and thiourea. The films were deposited on to the glass substrates at the selected temperature of 325,350 and $375^{\circ} \mathrm{C}$. The substrate temperature seems to be one of the more important parameters affecting the physical properties of the films. The films were fabricated at the lowest temperature have the least crystalline quality as was observed in XRD patterns. The resistivity of the films decreases with increasing the substrate temperatures. The analysis of the absorption curves for CdS films indicates a direct transition in the range of 2.44-2.45 $\mathrm{eV}$.

\section{References}

(1) http://www.grohol.com/psypsych/cadmiumsulfide.

(2) http://en.wikipedia.org/wiki/cadmiumsulfide.

(3) Sahay, P.P.; Nath, R. K. and Tewari, S., Cryst. Res. Technol, Vol.42, No.3, PP.275-280 (2007).

(4) Seshan, K., Handbook of Thin Film deposition processes and Techniques, $2^{\text {nd }}$ Edition, copyright by Noyes publication, U.S.A. (2002).

(5) Lee, J. and Lee, D., Thin Solid Films, Vol.515, pp.6055-6059 (2007).

(6) Kumar, V., MSC. Thesis, university of south Florida, (2003).

(7) Oliva, A.I.; Solis-Canto, O.; Castro-Rodriquez, R. and Quintana, P., Modern Physics Letters B, Vol.15, pp.671-674 (2001). 
(8) Morales-Acevedo, A.; Vigil-Galan, O. and Contreras-Puente, G., Physical properties of CdS Thin Films Grown by Different Techniques: A comparative Study, IEEE, (2002).

(9) Nair, P.K. and Nair, M.T.S., Solar Cells, Vol.22, pp.103-112 (1987).

(10) Samdami, Q.G.; Naseem, H.A. and Brown, W.D., Proceedings Arkansas Academy of Science, Vol. 49 (1995).

(11) Rami, M.; Benamar, E.; Fahoume, M.; Chraibi, F. and Ennaoui, A., M.J. Condensed Matter, Vol.3, No.1, pp.66-70 (2000).

(12) Ashour, A., Turk J Phys, Vol.27, pp.551-558 (2003).

(13) Tepantlan, C.S., Revista Mexicana De Fisica, Vol.54, pp.112-117 (2008).

(14) Georg, J., Preparation of thin films, copyright by Dekker, M., Inc. (1992).

(15) Ray, B. "II-VI compounds" pregaman press (1964).

(16) Ravichandran, K. and Philominathan, P., Solar energy, Vol.82, pp.1062-1066 (2008).

(17) Tigau, N., Cryst. Res. Technol., Vol.43, No.9, PP.964-969 (2008).

(18) Devi, R.; Purkayastha, P.; Kalita, P.K. Sarma, R.; Das, H.L. and Sarma, B.K., Indian Journal of Pure \& Applied Physics, Vol.45, PP.624-627 (2007). 